\title{
MEDIA ALTERNATIF PERTUMBUHAN Staphylococcus aureus DARI BIJI DURIAN (Durio zibethinus murr)
}

\author{
Siti Juariah $^{1 *}$, RiskaTiana ${ }^{2}$ \\ Universitas Abdurrab \\ J1. Riau Ujung, No 73 Pekanbaru Riau \\ *corresponding author, e-mail: sitijuariah@univrab.ac.id
}

\begin{abstract}
Media that is often used for bacterial growth is Nutrient agar. The high price incurred for the manufacture of instant media becomes a constraint so that innovation is needed that can reduce the cost of expenditure that is looking for alternative media from materials that are easily available. One of the natural ingredients that have a source of nutrients that can be used for bacterial growth of durian seeds that have a high carbohydrate content as a source of carbon. The objective of this research was to know the growth of Staphylococcus aureus bacteria on alternative medium of durian seed as substitution media of Nutrient agar. This research is laboratory experimental research, the sample used is durian seed with three concentrations of $200 \mathrm{~g}, 300 \mathrm{~g}, 400 \mathrm{~g}$. The parameters observed were calculating total plate number and morphological form of Staphylococcus aureus bacteria growth. The results showed that the highest population on medium durian medium was the concentration of $200 \mathrm{~g}$ as much as $5.7 \times 10^{-4} \mathrm{cfu}$ and the lowest population at the concentration of $400 \mathrm{~g}$ was $3.5 \times 10^{-3} \mathrm{cfu}$. While the population on the media Nutrient agar that is $7.7 \times 10^{-6} \mathrm{cfu}$. Based on morphological observation of bacterial growth on durian seed medium, round shape, size $0.1 \mathrm{~cm}$, white milk color, smooth surface, and convex elevation. The conclusion of this research is the growth of Staphylococcus aureus on alternative medium of durian seeds can be used as substitution media of Nutrient agar.
\end{abstract}

Keywords: Bacterial growth, Durian seed, Nutrient agar

\section{PENDAHULUAN}

Bakteri merupakan salah satu mikroba yang berukuran kecil dan tidak kasat mata, bakteri adalah organisme bersel tunggal yang bereproduksi dengan cara sederhana, yaitu dengan pembelahan biner. Bakteri memerlukan beberapa nutrisi untuk menunjang pertumbuhannya, sehingga dalam bidang mikrobiologi untuk menumbuhkan dan mempelajari sifat - sifat mikroorganisme, dilakukan rekayasa lingkungan, yaitu dengan memberikan media pertumbuhan yang memenuhi kebutuhan nutrisi yang di perlukan oleh bakteri, selain pemenuhan akan nutrisi kesesuaian lingkungan juga harus di perhatikan.

Menurut Atlas (2004) pertumbuhan mikroorganisme didalam suatu media buatan dipengaruhi oleh beberapa faktor fisik dan faktor kimia. Faktor fisik meliputi $\mathrm{pH}$ dan temperatur, sedangkan faktor kimia meliputi nutrisi yang terkandung dalam media pertumbuhan. Media yang digunakan harus mengandung nutrisi yang dibutuhkan mikroba misalnya dari sumber protein dan karbohidrat pada biji - bijian. Kemudian Cappucino (2013) menambahkan, media 
Juariah, S. dan R. Tiana: Media Alternatif Pertumbuhan Staphylococcus aureus dari Biji Durian (Durio zibethinus murr)

pertumbuhan harus memenuhi persyaratan nutrisi yang dibutuhkan oleh suatu mikroorganisme meliputi karbon, nitrogen, unsur non logam seperti sulfur dan fosfor, unsur logam seperti $\mathrm{Ca}, \mathrm{Zn}, \mathrm{Na}, \mathrm{K}, \mathrm{Cu}$, $\mathrm{Mn}, \mathrm{Mg}$, dan Fe, vitamin, air, dan energi.

Mahalnya harga yang di keluarkan untuk pembuatan media instant dalam memenuhi kebutuhan nutrisi yang di perlukan bakteri menjadi kendala yang sangat besar saat ini dalam pengembangan ilmu mikrobiologi. Sehingga diperlukan beberapa inovasi yang dapat mengurangi biaya pengeluaran dalam pembuatan media pertumbuhan mikrobiologi. Salah satu inovasi yang berkembang saat ini adalah dengan cara pemanfaatan sumber daya alam yang akan digunakan sebagai bahan pemenuhan nutrisi yang akan digunakan sebagai media pertumbuhan dengan biaya yang relatif lebih rendah dan mudah diperoleh.

Durian ( Durio Zibethinus Murr) merupakan salah satu buah yang mudah didapat, buah durian di juluki "The King $O f$ Fruit" karena kandungan gizinya yang lengkap dibanding buah yang lain, seperti kalium, magnesium, zat besi, fosfor seng, thiamin, ribovflavin, omega 3 dan 6 , Vitamin B dan C (Farida, 2012).

Bobot total buah durian terdiri dari tiga bagian, daging buah sekitar $20-35 \%$, kulit $60-75 \%$ dan biji, 5-15\% dari bobot total buah, masyarakat pada umunya hanya mengonsumsi daging buah durian, hal ini berarti $65-80 \%$ bagian kulit dan biji tidak dikonsumsi, biji durian dianggap tidak bermanfaat, ataupun sebatas dimanfaatkan untuk dimakan setelah direbus oleh sebagian kecil masyarakat (Suarti, 2013). Kemudian Djaeni dan Prasetaininggrum (2010) Secara fisik biji durian berwarna putih kekuning - kuningan berbentuk bulat telur berkeping dua. Biji durian mengandung gizi yang cukup banyak seperti protein, karbohidrat, lemak, kalsium, fosfor.

Melihat kandungan gizi biji durian dimungkinkan biji tersebut dapat dijadikan sebagai media pengganti untuk menumbuhkan bakteri. Beberapa peneliti telah melakukan penelitian tentang media bakteri menggunakan kentang, macam macam umbi, selain mudah didapat, bahan - bahan tersebut relatif murah bila dibandingkan dengan penggunaan media instant NA (Nutrient Agar) sehingga diharapkan dapat di gunakan sebagai media alternatif untuk penelitian di laboratorium (Anisah, 2015). Berdasarkan latar belakang di atas, maka penulis tertarik untuk meneliti apakah biji durian bisa menjadi media alternatif pertumbuhan bakteri Staphylococcus aureus. Tujuan dari penelitian ini adalah untuk mengetahui pertumbuhan bakteri Staphylococcus aureus pada media alternatif biji durian sebagai stubstitusi dari media NA. 
Juariah, S. dan R. Tiana: Media Alternatif Pertumbuhan Staphylococcus aureus dari Biji Durian (Durio zibethinus murr)

\section{METODE PENELITIAN}

Jenis penelitian ini bersifat deskriptif dengan desain penelitian eksperimental laboratory.

\section{Pembuatan Media}

Pelaksanaan penelitian diawali dengan proses sterilisasi alat yang di gunakan dalam penelitian, selanjutnya pembuatan media alternatif dari biji durian dengan cara merebus biji durian sebanyak 300 g kedalam $1000 \mathrm{ml}$ akuades, lalu menambahkan gula (gulaku) sebanyak $20 \mathrm{~g}$, agar (walet) $20 \mathrm{~g}$ ke dalam ekstrak. Selanjutnya di sterilkan dengan autoclave selama 15 menit suhu $121^{\circ} \mathrm{C}$ agar terbebas dari mikroba yang tidak diinginkan. Media menggunakan metode perbandingan dalam jumlah gram yaitu : $200 \mathrm{~g}$ dalam $1000 \mathrm{~mL}$, $300 \mathrm{~g}$ dalam $1000 \mathrm{~mL}, 400 \mathrm{~g}$ dalam 1000 $\mathrm{mL}$ (Ariyanti, 2016).

\section{Pembuatan Media NA (Nutrient Agar)}

Pada pembiakan Staphylococcus aureus media yang digunakan NA (Nutrient Agar). MediANA dibuat dengan cara di timbang 2,8 g, kemudian ditambahkan akuades $100 \mathrm{~mL}$, larutan tersebut kemudian dipanaskan diatas hot plate dan diaduk dengan magnetic stirrer hingga homogen, selanjutnya disterilisasi dengan autoclave selama 15 menit suhu $121{ }^{\circ} \mathrm{C}$. Media dituang ke dalam cawan petri secara aseptis, lalu dibiarkan di suhu ruangan hingga media memadat (Oxoid, 2015).

\section{Cara Kerja penanaman dengan metode} ALT

Siapkan 6 buah tabung reaksi steril dan beri label/nomor pada masing - masing tabung yang berisi $9 \mathrm{~mL} \mathrm{NaCl} 0,9 \%$ dan 1 tabung dijadikan sebagai kontrol. Ambil 1 $\mathrm{mL}$ suspensi lalu masukkan ke dalam tabung steril yang sudah berisi $9 \mathrm{~mL} \mathrm{NaCl}$ $0,9 \%$ kemudian homogenkan dan ini merupakan pengenceran $10^{-1}$ Ambil $1 \mathrm{~mL}$ dari tabung reaksi yang pertama pindahkan ke tabung reaksi yang kedua, homogenkan dan ini merupakan pengenceran $10^{-2}$, begitu seterusnya sampai menghasilkan pengenceran $10^{-5}$. Setelah itu ambil dari masing - masing pengenceran $\left(10^{-1}, 10^{-2}, 10^{-}\right.$ ${ }^{3}, 10^{-4}, 10^{-5}$ ) sebanyak $1 \mathrm{~mL}$ dimasukkan ke dalam petridish, kemudian tambahkan media $\mathrm{Na}$ atau media alternatif dengan suhu $45^{\circ} \mathrm{C}-50^{\circ} \mathrm{C}$ sebanyak $15-20 \mathrm{~mL}$. Homogenkan media lalu biarkan hingga memadat. Inkubasi pada suhu $37^{\circ} \mathrm{C}$ selama 2x24 jam dengan posisi agar diatas

\section{Perhitungan koloni dengan Colony Counter}

Perhitungan tiap - tiap petridish dilakukan oleh 2 orang yang memiliki syarat visus mata normal untuk memperkecil kesalahan perhitungan, apabila jumlah koloni yang tumbuh pada petridish kontrol lebih dari 10, pemeriksaan harus diulang karena sterilisasi dianggap kurang baik. Ideal jumlah koloni per plate yang boleh dihitung yaitu antara 30 sampai dengan $300 \mathrm{CFU}$ (Colony Form Unit). 
Juariah, S. dan R. Tiana: Media Alternatif Pertumbuhan Staphylococcus aureus dari Biji Durian (Durio zibethinus murr)

\section{Analisis Data}

Data yang diperoleh pada penelitian ini disajikan dalam bentuk tabel dan dianalisis secara deskriptif yaitu apakah media alternatif menggunakan biji durian dapat menumbuhkan bakteri Staphylococcus aureus.

\section{HASIL DAN PEMBAHASAN}

\section{Hasil Penelitian}

Penelitian pemeriksaan angka lempeng total pada media alternatif biji durian dan media Nutrient agar pada pertumbuhan Staphylococcus aureus yang dilakukan di didapatkan hasil pada Tabel 1 berikut :

\section{Tabel 1 Perhitungan Angka Lempeng Total Pada Media Alternatif Biji Durian dan Media Nutrient agar}

\begin{tabular}{|c|c|c|c|c|c|c|c|c|c|c|}
\hline \multirow{3}{*}{ No } & \multirow{3}{*}{ Perlakuan } & \multirow{3}{*}{ Ulangan } & \multicolumn{6}{|c|}{ Jumlah Kuman } & \multirow{3}{*}{$\begin{array}{l}\text { Angka } \\
\text { kuman }\end{array}$} & \multirow{3}{*}{ Rata - rata } \\
\hline & & & & & Peng & ence & & & & \\
\hline & & & $10^{1}$ & $10^{2}$ & $10^{3}$ & $10^{4}$ & $10^{5}$ & control & & \\
\hline 1 & $\mathrm{Na}$ & & 508 & 415 & 306 & 300 & 125 & 0 & $7.7 \times 10^{-6}$ & - \\
\hline \multirow[t]{3}{*}{2} & 200 gram & 1 & 405 & 333 & 58 & 31 & 18 & 2 & $1.7 \times 10^{-5}$ & \\
\hline & & 2 & 442 & 229 & 19 & 7 & 3 & 3 & $2.2 \times 10^{-4}$ & $5.7 \times 10^{-4}$ \\
\hline & & 3 & 10 & 4 & 2 & 1 & 1 & 2 & $8.0 \times 10^{-1}$ & \\
\hline \multirow[t]{3}{*}{3} & 300 gram & 1 & 40 & 39 & 36 & 31 & 20 & 2 & $8.2 \times 10^{-4}$ & \\
\hline & & 2 & 47 & 33 & 30 & 28 & 25 & 2 & $1.0 \times 10^{-4}$ & $3.1 \times 10^{-4}$ \\
\hline & & 3 & 33 & 31 & 25 & 25 & 23 & 2 & $1.6 \times 10^{-3}$ & \\
\hline \multirow[t]{3}{*}{4} & 400 gram & 1 & 30 & 20 & 36 & 31 & 28 & 2 & $1.0 \times 10^{-4}$ & \\
\hline & & 2 & 25 & 22 & 22 & 15 & 15 & 2 & $2_{2}^{2.3 \times 10^{-}}$ & $3.5 \times 10^{-3}$ \\
\hline & & 3 & 35 & 25 & 22 & 15 & 13 & 2 & $3.3 \times 10^{-2}$ & \\
\hline
\end{tabular}

Berdasarkan hasil pemeriksaan angka lempeng total pada tabel 1 didapatkan hasil jumlah angka lempeng total pada media Nurtient agar adalah $7.7 \mathrm{x}$ $10^{-6} \mathrm{cfu}$. Pada media alternatif biji durian didapatkan rata - rata dari konsentarsi 200 gram yaitu $5.7 \times 10^{-4} \mathrm{cfu}$, konsentrasi 300 gram $3.1 \times 10^{-4} \mathrm{cfu}$, konsentrasi 400 gram $3.5 \times 10^{-3} \mathrm{cfu}$. 
Juariah, S. dan R. Tiana: Media Alternatif Pertumbuhan Staphylococcus aureus dari Biji Durian (Durio zibethinus murr)

Tabel 2. Hasil Morfologi Pertumbuhan Pada Media

\begin{tabular}{ccc}
\hline Spesifikasi & Media Na & Media biji durian \\
\hline Bentuk koloni & Bulat & Bulat \\
Ukuran & Kecil $0.1 \mathrm{~cm}$ & Kecil $0.1 \mathrm{~cm}$ \\
Warna & Kuning & Putih susu \\
Permukaan & Halus & Halus \\
Elevasi & Cembung & Cembung \\
\hline
\end{tabular}

Berdasarkan hasil pengamatan pertumbuhan bakteri Staphylococcus aureus pada tabel 2 didapatkan hasil pertumbuhan pada media NA adalah bentuk koloni bulat, ukuran kecil $0.1 \mathrm{~cm}$, warna kuning, permukaan halus dan elevasi cembung. Pertumbuhan pada media biji durian adalah bentuk bulat, ukuran $0,1 \mathrm{~cm}$, warna putih susu, permukaan halus, dan elevasi cembung.

\section{Pembahasan}

Penelitian ini dilakukan dengan menggunakan biji durian segaryang didapat dari kebun durian yang terletak di Kampar - Bangkinang. Dalam penelitian ini menggunakan konsentrasi biji durian yang berbeda - beda yaitu dengan konsentrasi $200 \mathrm{~g}, 300 \mathrm{~g}, 400 \mathrm{~g}$ masing - masing dalam $1000 \mathrm{~mL}$ akuades. Pertumbuhan bakteri Staphylococcus aureus dengan memanfaatkan media biji durian dapat diketahui bahwa hasil populasi tertinggi pada konsentrasi $200 \mathrm{~g}$ sebanyak $5.7 \times 10^{-4}$ cfu dan populasi terendah pada konsentrasi $400 \mathrm{~g}$ yaitu $3.5 \times 10^{-3} \mathrm{cfu}$, koloni yang dihasilkan berbentuk bulat dan berwarna putih susu.

Dilihat dari hasil penelitian yang diperoleh dapat diketahui bahwa pada konsentrasi terendah petumbuhan bakteri yang lebih bagus, karena semakin rendah konsentrasi maka semakin sedikit pula lendir dari biji durian tersebut. Sedangkan pada kontrol dengan media NA memiliki populasi 7.7 x $10^{-6}$ cfu. koloni yang dihasilkan berbentuk bulat dan berwarna kekuningan. Perlakuan menggunakan media NA menunjukkan hasil yang optimal dalam ukuran koloni bakteri sehingga mudah diamati. Jika dibandingkan dengan media alternatif biji durian yaitu ukuran koloni yang lebih kecil tetapi jumlahnya lebih banyak.

Pada penelitian yang dilakukan hasil perlakuan menggunakan media NA yaitu koloni menghasilkan pigmen berwarna kuning dan koloni yang terbentuk terlihat lebih besar serta mudah diamati. Hal ini dikarenakan media NA merupakan media yang sudah teruji secara klinis baik untuk pertumbuhan bakteri, sehingga proses metabolisme bakteri berlangsung sempurna, 
Juariah, S. dan R. Tiana: Media Alternatif Pertumbuhan Staphylococcus aureus dari Biji Durian (Durio zibethinus murr)

sedangkan pada media alternatif biji durian memiliki nutrisi yang lebih kompleks sehingga pertumbuhan bakteri tidak sempurna pada media NA.

Kandungan kompleks dalam media menyebabkan pertumbuhan mikroorganisme membutuhkan waktu yang lebih lama untuk menguraikan komponen komponen sederhana yang dapat diserap sel dan digunakan untuk sintesis sel dan energi, dan perbedaan pertumbuhan bakteri dapat pula dipengaruhi oleh kandungan nutrisi, $\mathrm{pH}$, temperatur, aerasi, konsentrasi garam dan kekuatan ionik medium (Jawetz, 2005).

Berdasarkan penelitian sebelumnya dari Purwati, (2016) media pertumbuhan bakteri dengan bahan umbi seweg, umbi talas dan umbi kimpul menghasilkan jumlah koloni yang banyak akan tetapi ukuran koloninya seperti titik - titik. Dan berdasarkan penelitian sebelumnya dari Anisah, (2015) media pertumbuhan bakteri dengan bahan umbi ganyong, umbi garut, dan umbi gembili menghasilkan koloni bakteri yang besar dan hampir menyerupai koloni bakteri yang tumbuh pada media Nutrient agar. Hal ini dikarenakan bahwa umbi ganyong, umbi garut, dan umbi gembili tidak mengandung lendir sama sekali sehingga pertumbuhannya sangat baik.

\section{Kesimpulan}

Berdsarkan hasil penelitian yang telah dilakukan pertumbuhan yang optimal terdapat pada konsentasi $200 \mathrm{~g}$ yaitu $5.7 \mathrm{X}$ $10^{-4}$ cfu. karena lendir yang dihasilkan lebih sedikit dan morfologi dari media biji durian koloninya berbentuk bulat berwarna putih susu sehingga biji durian dapat dijadikan sebagai media alternatif untuk pertumbuhan bakteri.

\section{DAFTAR PUSTAKA}

Amir, Farida dan Chairul Saleh. 2014. Uji Aktivitas Antioksidan Estrak Etanol

Biji Durian (Durio zibethinus murr) Dengan Menggunakan Metode DPPH. Jurnal Kimia Mulawarman, Vol.11, No 2

Anisah, 2015. "Media Alternatif untuk Pertumbuhan Bakteri Menggunakan Sumber Karbohidrat yang Berbeda". Skripsi. Fakultas Keguruan dan Ilmu Pendidikan, Universitas Muhammadiyah. Surakarta

Ariyanti, widya. 2016. Pertumbuhan Bakteri E.coli Dan Bacillus subtilis Pada Media Singkong, Ubi Jalar Putih, dan Ubi Jalar Kuning Sebagai Substitusi Media NA. Skripsi. Fakultas Keguruan dan Ilmu Pendidikan Universitas Muhammadiyah .Surakarta

Atlas, Ronald M. 2004. Handbook of Microbiological Media fourth Edition

Volume 1. United states Of America: CRC press

Cappuccino, J. G dan Natalie, S. 2013. Manual Laboratorium Biologi; ahli bahasa, Nur Miftahurrahman. EGC. Jakarta

CLSI, 2006. Protocols for Evaluating Dehydrated Mueller - Histon Agar ;

Meditory | ISSN Online : 2549-1520, ISSN Cetak : 2338 - 1159, Vol. 9, No. 1, Juni 2021 
Juariah, S. dan R. Tiana: Media Alternatif Pertumbuhan Staphylococcus aureus dari Biji Durian (Durio zibethinus murr)

Approved Stand ard - Second Edition. CLSI document M06 - A2. Wayne, PA: Clinical and Laboratory Standarts Institute

Djaeni. Moh, A. Prasetyaninggrum, 2010. Kelayakan Biji Durian Sebagai Bahan

Pangan Alternatif: Aspek Nutrisi dan Tekno Ekonomi. Riptek, Vol.4, No,11. Hal :37 - 45 .

Jawetz, Melnick, dan Adelberg's, 2005. Mikrobiologi Kedokteran. Salemba Medika. Jakarta.
Purwati, suci. 2016. "pemanfaatan Sumber Karbohidrat yang Berbeda (umbi suweg, umbi talas, dan umbi kimpul) Sebagai Media NA untuk Pertubuhan Bakteri" Skripsi. Fakultas Keguruan dan Ilmu Pendidikan, Universitas Muhammadiyah. Surakarta

Suarti Budi, dkk. 2013. Pembuatan Pati Dari Biji Durian Melalui Penambahan Natrium Metabisulfit dan Lama Perendaman. Agrium. Vol 18. No 1. 